\title{
Factors affecting the adoption of blended learning strategy
}

\author{
Sura I. Al-Ayed ${ }^{\mathrm{a}}$ and Ahmad Adnan Al-Tit ${ }^{\mathrm{b}^{*}}$
}

${ }^{a}$ College of Administration and Financial Sciences, Saudi Electronic University, AlRiyadh, Saudi Arabia

${ }^{b}$ Department of Business Administration, College of Business and Economics (CBE), Qassim University, KSA. Al Malida, Buraidah, 15452, Qassim, Kingdom of Saudi Arabia

\section{H R O N I C L E}

Article history:

Received: March 13, 202

Received in revised format: April

10,2021

Accepted: June 12, 2021

Available online: June 13, 2021

Keywords:

E-Learning

Humans

Institutional

Blended Learning Strategy

Adoption

Business Education

\begin{abstract}
A B S T R A C T
The aim of this study is to explore factors affecting the adoption of blended learning strategy. Data was collected using a questionnaire consisting of 42 items, distributed to a random sample of 174 faculty members of Saudi Electronic University and Qassim University. IBM SPSS was used to conduct data analysis. Supporting research hypothesis indicates that student, institutional and learning variables had significant influences on the adoption of blended learning strategy. Considering the findings, it was concluded that the adoption of a blended learning strategy depends not only on the technological aspect of the learning process but also on people, i.e., students who are engaged in the process and motivated teachers who possess the required knowledge and skills. The most important implication of this research is that policy and decision makers in business educational schools are requested to consider factors that had a significant effect on the adoption of blended learning. In doing that, the research contributes to the blended learning knowledge via highlighting the key variables that encourage or hinder the adoption of blended learning strategy.
\end{abstract}

\section{Introduction}

Blended learning (BL) can be divided into two types: research on educational institutions like universities (Garrison \& Kanuka, 2004; Delialioglu \& Yildirim, 2007; Owston et al., 2013; Porter et al., 2014) and schools (Al-Awad \& Al-Yones, 2011; Al-Zu'bi \& Bani-Domi, 2012), and research on non-educational institutions such as business organizations (Baldwin-Evans, 2006) or medical institutions (Makhdoom et al., 2013). Research on blended learning tackled numerous topics like perceptions of learning process in blended learning environment (Ellis et al., 2006; Vaughan, 2007; So \& Brush, 2008; Owston et al., 2013), a comparison between traditional and blended learning methods (Rovai \& Jordan, 2004, Fazal \& Bryant, 2019, Hwang et al., 2019), future directions of blended learning (Bonk et al., 2006), success factors for blended learning (Mitchell \& Honore, 2007; Stacey \& Gerbic, 2008; Harris et al., 2009), the effectiveness of blended learning (Pereira et al., 2007; Wall \& Ahmed, 2008; Means et al., 2013), blended learning system design (George-Walker \& Keeffe, 2010), adoption and implementation of blended learning (Graham et al., 2013) in addition to the effect of blended learning model on students' achievement (Al-Ani, 2013) and satisfaction (Al lHassan \& Shukri, 2017).

The positive impact of blended learning strategy on students' educational performance was documented in the literature (Abdulrahman, 2016). Using a random sample consisting of 73 students divided into a control group taught by a traditional method and an experimental group learned by blended learning as well as 213 teachers, Al-Ghamdi (2013) found that there were significant differences between students' achievement in favor of the experimental group. Al-Zu'bi and Bani-Domi (2012) investigated the effect of blended learning on the achievement of fourth grade students in mathematics. Their results showed significant differences between students in favor of the experimental group, which instructed using a blended learning strategy.

* Corresponding author.

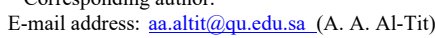

(C) 2021 by the authors; licensee Growing Science, Canada. doi: $10.5267 /$ j.ijdns.2021.6.007 
Success factors and barriers of blended learning strategy adoption were also studied by numerous researchers. In a study applied to educational supervisors and teachers to explore importance, utilization, and barriers of blended learning, Al-Fuhaid (2015) identified some instructional factors that affect the adoption of blended learning related to the Internet, computers, programs, and e-content. Harris et al. (2009) argued that there are significant requirements that should be considered in the context of blended learning adoption and implementation, e.g., human factors such as training, motivation, and satisfaction in addition to technology factors like access and learning factors such as learning outcomes. According to Riyami et al. (2019), teacher training and leaner collaboration are two important factors required for the integration of information and communication technologies for education. Despite the literature on blended learning, it was noted that most studies were carried out on higher education institutions. In a review of doctoral dissertations and master's theses on blended learning, Drysdale et al. (2013) confirmed this result. On the other hand, the requirements for adoption of integrated education in basic schools are different from those to be provided in higher education levels. Consequently, the aim of this study is to study signify factors affecting the adoption of blended learning adoption in business education. According to Harris et al. (2009), investigating valuable factors that influence blended learning prior to adoption and implementation of this strategy is a very critical effort.

\section{Literature review and hypotheses development}

\subsection{Definition of blended learning}

Blended learning as the name implies, is a mixture of traditional teaching methods and e-learning activities. Lim and Morris (2009) defined this concept as a mix consisting of using face-to-face instructional methods with learning technology. For Larson and Murray (2008), it is a bridge between traditional and online teaching. Halverson et al. (2012) conceptualized this concept as a combination of face-to-face and online learning modalities. Delialioglu and Yildirim (2007) used blended learning and hybrid instruction as interchangeable terms by which the authors mean a learning environment in which the attributes of traditional (e.g., student-peer and teacher interaction) and online (e.g., information access via web) learning are combined. For the current study, blended learning is defined as a learning modality delivered to students based on social direct interactions between students, peers and teachers and online interactions. Blended learning involves numerous approaches such as formal (teacher-led classrooms) and informal (e.g., role modeling and collegial connections) live face-to-face approaches, formal (live e-learning classes) and informal (e.g., emails and online communities) virtual collaborations, self-paced learning (e.g., online resource links, simulations, web-learning modules, online self-assessment and workbooks), as well as performance support via knowledge databases, help systems, documentation, and performance support tools (Singh, 2003; Rossett, 2003).

\subsection{Success factors of blended learning}

Success of blended learning has been deemed by Stacey and Gerbic (2008) as a concept related to learning practices that result in a high-quality learning outcome, a high level of student learning experience and a high level of teacher satisfaction, considering that learning using this modality requires an acceptable workload. A key vein of the literature on blended learning examined factors affecting students' performance or learning outcomes in blended learning environments. Lim and Morris (2009) studied the effect of learner and instructional variables on learning outcomes and found that leaner, instructional, and motivational variables had significant effects on learning outcomes, i.e., perceived learning application. Salameh (2005, cited in Al-Zu'bi \& Bani-Domi, 2012) identified some factors of blended learning success such as student-teacher interaction, teamwork, flexible test, continuous communication, content frequency, and enhancing student self-learning. Al-Hadhoud \& Al-Hattami (2017) indicated that the implementation of blended learning is still limited to some obstacles such as lack of Internet access, classroom congestion, limited computerized curriculum, and low skills of using Internet and computers, lack of training on the implementation of blended learning, interrupted training of new teachers, and theoretical training course. Al-Fuhaid (2015) conducted a study to identify the current utilization as well as requirements and obstacles of blended learning using a sample of educational supervisors and teachers from Qassim region, Saudi Arabia. The results pointed out that the availability of computer labs at the school, data show devices at the school, web-based learning content, Internet or Intranet at the school, smart boards at the school, virtual classrooms, interactive e-courses, learning management system, and personal computers for students' use. Harris et al. (2009) provided practical recommendations on adoption and implementation of blended learning. These recommendations include evaluation of blended learning in terms of cost effectiveness and student motivation and satisfaction, resources access and usability of blended learning system, adequate training for educational staff and students, learning outcomes, and technology. Creditability, accessibility, flexibility, personalization, transparency, productivity, and interactivity are success factors that motivate students to participate in online and blended learning (Blieck et al., 2019). Course structure, emotional support and communication medium was identified by So and Brush (2008) as success factors of collaborative learning in a blended learning environment. In their paper in blending learning approaches, Alammary et al. (2014) identified three approaches: low-impact, medium-impact, and high-impact designs. In the first approach, the teacher adds extra activities to the existing course, while in the second one, the teacher replaces some activities in the existing course, whilst he or she in the high-impact design builds a new blended course. Apart from specific design, the authors identified some challenges in this regard such as teachers' technological knowledge, inadequate compensation and incentives, lack of prior experience in teaching the traditional course, and teachers' skills in designing e-courses.

Mozelius and Hettiarachchi (2017) mentioned other critical factors for the implementation of blended learning included technology, instructional design, and teacher's role, learning outcomes and learner satisfaction, social interactions between learning participants, course design, and synchronous and asynchronous features of course activities. Factors that affect the successful implementation of 
blended learning were divided into three categories, i.e., human, instructional and learning factors. To investigate the effects of these factors on the success of blended learning implementation, the following hypotheses were postulated:

$\mathbf{H}_{1}$ : Human variables predict blended learning adoption.

H2: Instructional variables predict blended learning adoption.

H3: Learning variables predict blended learning adoption.

\section{Methods}

\subsection{Sample and data collection}

The sample of the study consisted of 200 faculty members of Saudi Electronic University and Qassim University, in the second semester, 2020. Data was collected using an e-questionnaire by email consisting of 42 items distributed to the members of the sample. Out of the distributed questionnaires, 174 questionnaires were returned complete and valid for data analysis, with a recovery rate of $\% 87$.

\subsection{Measures}

A questionnaire was developed with reference to related works (e.g., Lim \& Morris, 2009; Harris et al., 2009; Al-Zu'bi \& BaniDomi, 2012; Poon, 2013; Al-Fuhaid, 2015; Wang et al., 2015; Al-Hadhoud \& Al-Hattami, 2017; Blieck et al., 2019, Riyami et al., 2019) to collect data on human, institutional and learning variables. Human factors were measured by students' sufficient knowledge, students' competency to learn independently, students' experience in using technological tools such as computers and the Internet, students' satisfaction with blended learning, faculty sufficient knowledge, faculty experience in traditional teaching, faculty experience in blended learning, and faculty related training. As shown in Table 1, sixteen items were used to measure human variables (116). Institutional variables were measured by four dimensions, resources, faculty support, student support and blended learning effectiveness. The overall items used to measure these dimensions were eight items (17-24). Learning variables were evaluated by three dimensions related to motivation, interactions, and outcomes. Six items were used to assess these variables (25-30).

In their framework for adoption and implementation of blended learning, Graham et al. (2013) identified the following stages: awareness/exploration, adoption/early implementation, and mature implementation/growth. As cited in Porter et al. (2016), in the first stage the institution has no strategy of blended learning but there is a good level of awareness among administrators on blended learning with some support for faculty to apply this strategy. In the second stage, the institution adopts a strategy for blended learning with an early effort to implement this strategy. In the third stage, the institution has its own strategy, structure, and support for blended learning. Porter and Graham (2016) investigated drivers and barriers of blended learning adoption and pointed out that sufficient infrastructure, technological and instructional support, evaluation data as well as an institution's purpose are key drivers of blended learning adoption. Brown (2016) reviewed the literature on faculty adoption of blended learning practice and identified faculty interaction with technology and students, attitudes, academic workload, development opportunities and institutional environment as drivers of adoption.

Table 1

Questionnaire items

\begin{tabular}{|c|c|c|c|}
\hline Variables & Dimensions & No. & Items \\
\hline \multirow{8}{*}{ Human variables } & \multirow{4}{*}{ Student variables } & $1-2$ & Sufficient knowledge \\
\hline & & $3-4$ & Competency to learn independently \\
\hline & & $5-6$ & Experience in using technological tools \\
\hline & & $7-8$ & Student preference of blended learning \\
\hline & \multirow{4}{*}{ Faculty variables } & $9-10$ & Sufficient knowledge \\
\hline & & $11-12$ & Experience in traditional teaching \\
\hline & & $13-14$ & Experience in blended learning \\
\hline & & $15-16$ & Faculty related training \\
\hline \multirow{4}{*}{ Institutional variables } & Resources & $17-18$ & Finance, time and effort \\
\hline & Faculty support & $19-20$ & Support for teachers from senior management \\
\hline & Student support & $21-22$ & Student support to ensure high involvement \\
\hline & Effectiveness & $23-24$ & Suitability of blended learning method \\
\hline \multirow{3}{*}{ Learning variables } & Motivation & $25-26$ & Student and faculty motivations \\
\hline & Interaction & $27-28$ & Student-peer- faculty interactions \\
\hline & Outcomes & $29-30$ & Learning outcomes \\
\hline \multirow{6}{*}{$\begin{array}{c}\text { Adoption of blended learn- } \\
\text { ing }\end{array}$} & \multirow{3}{*}{ Administration adoption } & $31-32$ & Administration awareness and attitudes \\
\hline & & $33-34$ & Presence of a blended learning strategy \\
\hline & & $35-36$ & Technological and instructional support \\
\hline & \multirow{3}{*}{ Faculty adoption } & $37-38$ & Faculty beliefs about blended learning \\
\hline & & $39-40$ & Faculty workload \\
\hline & & $41-42$ & Faculty incentives and development \\
\hline
\end{tabular}


For the current study, blended learning adoption was measured by 12 items, 6 items to measure administration adoption of blended learning and 6 items to measure teacher adoption of blended learning. Examples of items used to evaluate administration and faculty adoption include "our administration has positive attitudes toward blended learning" and "my workload encourages me to adopt blended learning".

\subsection{Conceptual and Measurement model}

Fig. 1 shows the conceptual model of this research. It portrays three hypotheses suggested to investigate the effect of student variables, institutional variables, and learning variables on the adoption of blended learning.

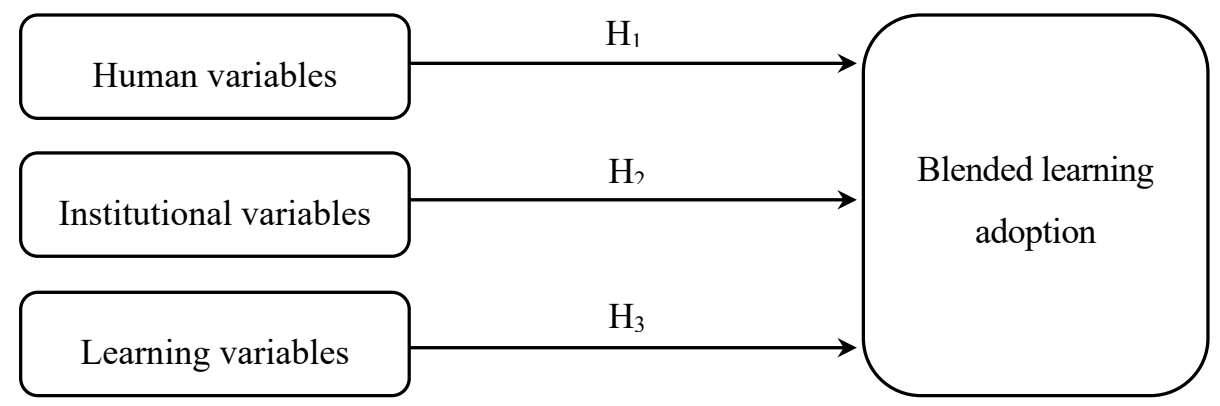

Fig. 1. Research conceptual model

The conceptual model was measured through confirmatory factor analysis (CFA). Two major benefits were achieved using this analysis, which was conducted based on exploratory factor analysis (EFA), first, to assess validity and reliability and, second, to check the goodness-of-fit indices (Al-Tit, Omri \& Hadj, 2020).

Table 2

Results of exploratory factor analysis

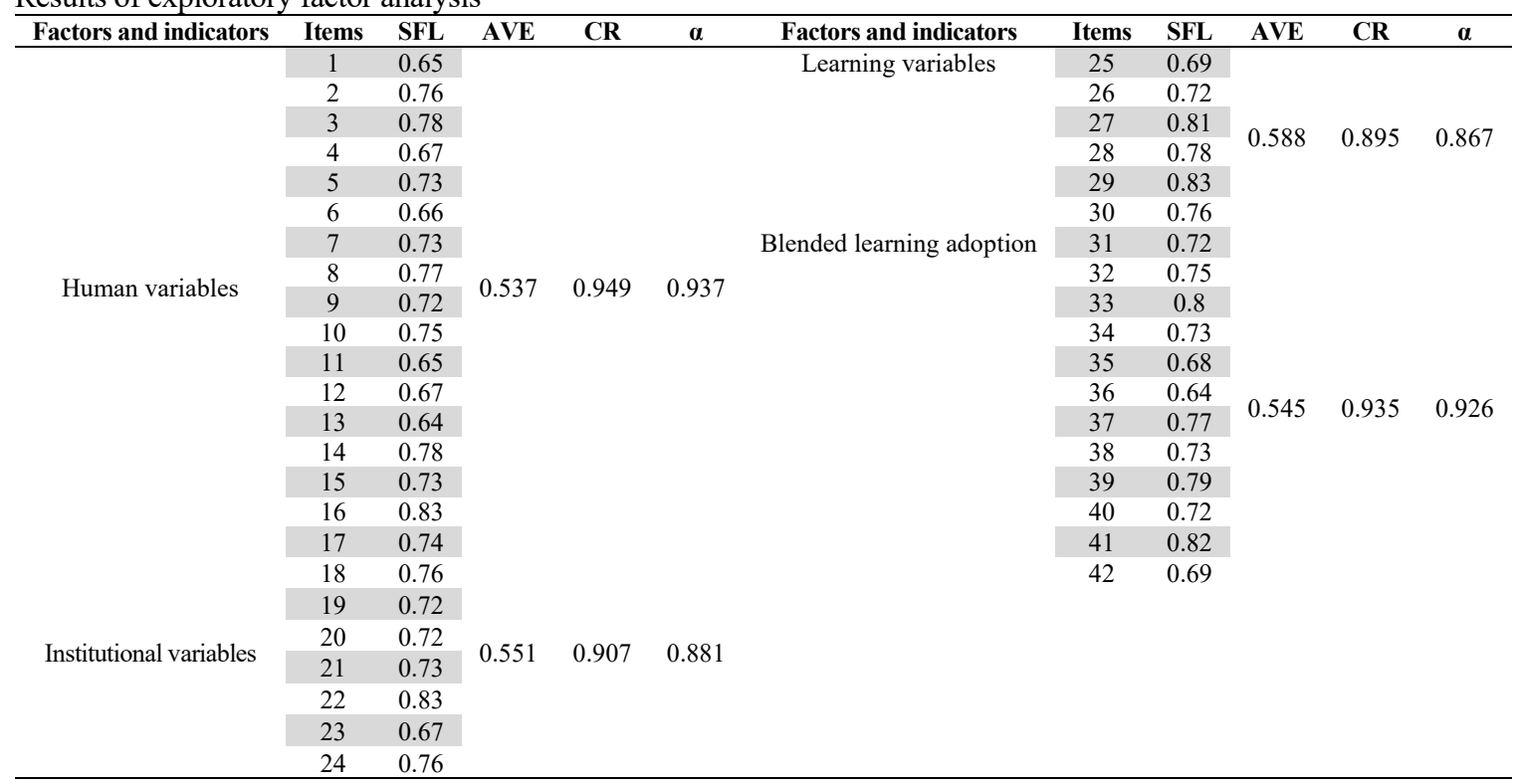

The results of EFA as shown in Table 2 indicate that all standardized factor loadings (SFL) are greater than 0.7 and the average variance extracted (AVE) are greater than 0.5. The results of AVE confirmed convergent validity (Cheon et al., 2012; Euchi, Omri, Al-Tit, 2018). Composite reliability (CR) and Cronbach's alpha $(\alpha)$ are greater than 0.7 (Shevlin \& Adamson, 2005; Cheon et al., 2012; Mohammed et al., 2017). These results asserted that the entire scale is valid and reliable.

The results in Table 3 show that the measurement model had a good fit. Chi-square/degree of freedom $\left(\chi^{2} / \mathrm{df}\right)$ equals 1.97 which is less than 3 (Vodanovich et al., 2005), the goodness-of-fit-index (GFI) and the comparative fit index (CFI) are higher than 0.90 (Rahman et al., 2012), and the root mean square error of approximation (RMSEA) is less than 0.08 (Schermelleh-Engel et al., 2003). 
Table 3

Measurement model goodness-of-fit

\begin{tabular}{|c|c|c|c|}
\hline Indices & Criteria & Value & Result \\
\hline Chi-square/df ratio ( $\chi 2 / \mathrm{df})$ & $<3.00$ & 1.97 & accepted \\
\hline Goodness-of-fit index (GFI) & $>0.90$ & 0.94 & accepted \\
\hline Comparative fit index (CFI) & $>0.90$ & 0.93 & accepted \\
\hline The root mean square error of approximation (RMSEA) & $<0.08$ & 0.04 & accepted \\
\hline
\end{tabular}

\section{Results and discussion}

\subsection{Descriptive statistics and correlations}

Means and standard deviations were calculated for independent and dependent variables in order to rank respondents' estimations based on their responses on scale items. Further, Pearson correlations were computed to identify the extent to which research variables are correlated to each other. Table 4 depicts these results.

Table 4

Means, SDs and Pearson correlations

\begin{tabular}{lllccc}
\multicolumn{1}{c}{ Variables } & Means & SDs & $\mathbf{1}$ & $\mathbf{2}$ & \\
\hline 1. Human variables & 3.57 & 0.85 & - & & \\
2. Institutional variables & 3.71 & 0.66 & $0.41^{*}$ & - & \\
3. Learning variables & 3.43 & 0.71 & $0.53^{*}$ & $0.38^{*}$ & - \\
4. Blended learning adoption & 3.64 & 0.59 & $0.46^{*}$ & $0.63^{*}$ & $0.55^{*}$ \\
\hline
\end{tabular}

* significant at $a \leq 0.05$

Results in Table 4 highlight that the overall degree of human variables is moderate $(\mathrm{M}=3.57, \mathrm{SD}=0.85)$, institutional variables is high $(\mathrm{M}=3.71, \mathrm{SD}=0.66)$, learning variables is moderate $(\mathrm{M}=3.43, \mathrm{SD}=0.71)$ and the overall degree of blended learning adoption is moderate $(\mathrm{M}=3.64, \mathrm{SD}=0.59)$. Furthermore, the results indicate that the independent variables are significantly correlated to each other and to the dependent variable. Human variables are significantly and positively correlated to blended learning adoption $(\mathrm{r}=0.46, \mathrm{P}<0.05)$, as are institutional variables $(\mathrm{r}=0.63, \mathrm{P}<0.05)$ and learning variables $(\mathrm{r}=0.55, \mathrm{P}<0.05)$.

\subsection{Path model}

The path model portrayed in Figure 2 was established in order to test research hypotheses. The model shows that human, institutional and learning variables had significant effects on the adoption of blended learning strategy.

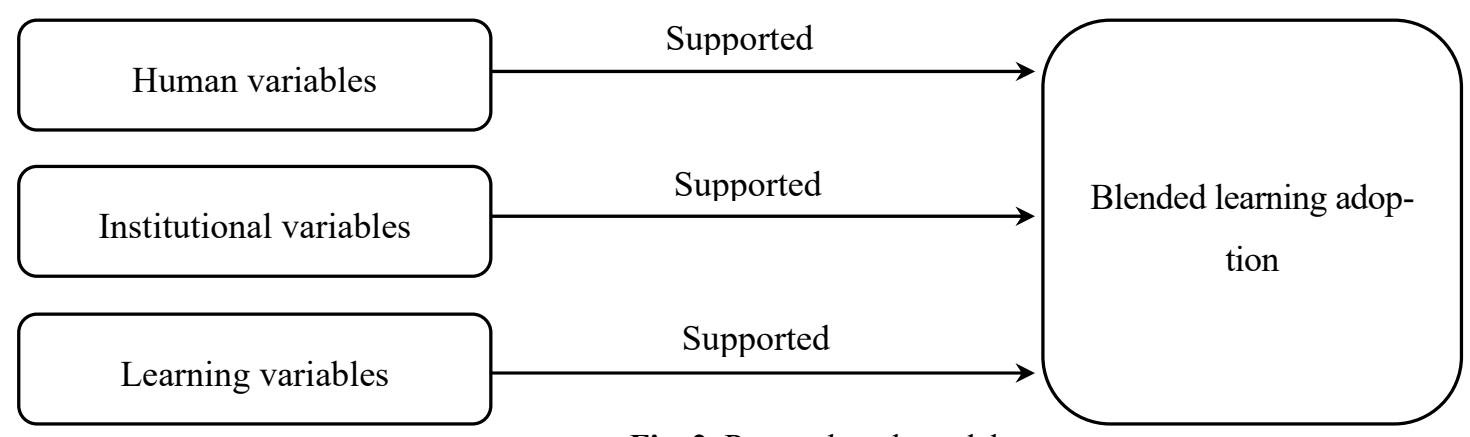

Fig. 2. Research path model

The results of path analysis in which research hypotheses were tested can be seen in Table 5. It was revealed that human, institutional and learning variables had significant effects on the adoption of blended learning.

Table 5

Results of path analysis

\begin{tabular}{lccccc}
\multicolumn{1}{c}{ IVs } & Direction & DV & $\beta$ & t & P-value \\
\hline Human variables & $\rightarrow$ & BLA & 0.43 & 4.77 & 0.000 \\
Institutional variables & $\rightarrow$ & BLA & 0.51 & 9.28 & 0.001 \\
Learning variables & $\rightarrow$ & BLA & 0.37 & 3.89 & 0.000 \\
\hline
\end{tabular}

* dependent variable: blended learning adoption 
The results of hypotheses testing displayed in Table 5 indicate that the institutional variables exerted the most significant effect on the adoption of blended learning $(\beta=0.51$, t-value $=9.28$, $\mathrm{p}$-value $=0.001)$, followed by human variables $(\beta=0.43$, $\mathrm{t}$-value $=4.77, \mathrm{p}$-value $=0.000)$ and then learning variables $(\beta=0.37$, t-value $=3.89, \mathrm{p}$-value $=0.000)$.

\section{Conclusion and implications}

The aim of this study was to investigate drivers affecting the adoption of blended learning. Three key drivers were identified based on an intensive literature review: human factors, institutional variables and learning variables. Evaluating the effect of these drivers and their associated dimensions on the adoption of blended learning for the perspectives of students revealed that the intended drivers are significant drivers of this learning modality. Considering these results, policy and decision makers are required not only to consider physical factors that encourage the adoption of blended learning but also the human factors, since a key ingredient of blending learning is social interactions among students, peers and teachers in a learning environment in which the learning process is conducted traditionally and electronically.

In fact, our results agree with several early studies concerned with the adoption of blended learning. In terms of institutional variables, researchers found some factors that affect the adoption of blended learning in this regard. Examples include technological and instructional resources (Al-Fuhaid, 2015, Mozelius \& Hettiarachchi, 2017, Al-Hadhoud \& Al-Hattami, 2017), and effectiveness of blended learning (Harris et al., 2009). For human factors, our results had been echoed in previous related works. Some of these factors found are student motivation and satisfaction (Harris et al., 2009, Mozelius and Hettiarachchi, 2017), compensation and incentives, lack of prior experience in teaching the traditional course, and faculty members skills in designing e-courses (Alammary et al., 2014) as well as student involvement blended learning (Alijani et al., 2014). Learning variables, which measured by student and teacher motivations, student-peer-faculty interactions, and learning outcomes, had been regarded in the literature as key drivers of blended learning adoption and faculty adequate training (Lim and Morris, 2009, AlHadhoud \& Al-Hattami, 2017), interactivity among learning participants (Blieck et al., 2019), learning outcomes (Harris et al., 2009, Al-Zu'bi and Bani-Domi, 2012), and learners technological skills (Al-Hadhoud \& Al-Hattami, 2017).

Research participants perceived institutional drivers such as resources, student, and teacher support along with effectiveness as the most important factors of blended learning adoption, therefore, educational administrators and supervisors should take into account availability of financial resources, time and effort required to implement blended learning. They are also called to support both students and teachers to assure their positive involvement. Effectiveness of blended learning in terms of cost, usability and suitability should be a major priority of blended learning adoption and implementation. Furthermore, sufficient knowledge of students and faculty members are no less important than their preferences and skills in this regard. Finally, students and faculty members' motivations and interactions should be recognized and enhanced in order to encourage the adoption of blended learning.

\section{Limitations and future trends}

The results of the current research are limited to the sample from which data were gathered. The research was applied to 174 faculty members of Saudi Electronic University and Qassim University; therefore, larger samples are required to make our results more generalized. Additionally, the research is limited to its cross-sectional design, hence, longitudinal studies should be carried out to gain a comprehensive understanding of the effects of human, institutional and learning variables on blended learning adoption.

\section{Availability of data and material}

The data generated during and/or analyzed during the current study are available from the corresponding author on reasonable request.

\section{Funding}

The authors extend their appreciation to the Deputyship for Research \& Innovation, Ministry of Education in Saudi Arabia for funding this research work through the project number 7849 .

\section{Acknowledgements}

The authors would like to thank the respondents who participated in this research. They would also like to thank the Deanship of Scientific Research in Saudi Electronic University, Riyadh, Saudi Arabia.

\section{References}

Abdulrahman, A. (2016). The effect of blended learning strategy on Islamic scientific college students and the development of their jurisprudential concepts. Diyala Journal of Human Research, 69, 309-339.

Al lHassan, S., \& Shukri, N. (2017). The effect of blended learning in enhancing Female students' satisfaction in the Saudi context. English Language Teaching, 10(6), 190-203.

Alammary, A., Sheard, J., \& Carbone, A. (2014). Blended learning in higher education: Three different design approaches. Australasian Journal of Educational Technology, 30(4), 440-454. 
Al-Ani, W. T. (2013). Blended learning approach using Moodle and student's achievement at Sultan Qaboos University in Oman. Journal of Education and Learning, 2(3), 96-110.

Al-Awad, F., \& Al-Yones, Y. (2011). The effect of using a blended teaching method on eighth grade students' achievement in functions and equations solving units. Dirasat: Educational Sciences, 38(2), 2351-2368.

Al-Fuhaid, T. F. (2015). The current utilization of blended learning in the teaching of natural sciences in secondary schools: Perspectives of educational supervisors and teachers of sciences in Qassim region. A Master Thesis, Umm Al-Qura University, Saudi Arabia.

Al-Ghamdi (2013). The effect of blended learning on the achievement of students at the second grade secondary in Arabic subject in Jeddah governorate and teachers attitudes toward it. A Master Thesis, Yarmouk University, Irbid, Jordan.

Alijani, G. S., Kwun, O., \& Yu, Y. (2014). Effectiveness of blended learning in KIPP new Orleans's schools. Academy of Educational Leadership Journal, 18(2), 125-141.

Al-Tit, A. A., Omri, A., \& Hadj, T. B. (2020). The driving factors of the social commerce intention of Saudi Arabia's online communities. International Journal of Engineering Business Management, 12, 1-8. https://doi.org/10.1177/1847979019899746

Al-Zu'bi, A., \& Bani-Domi, H. (2012). The effect of blended learning on the achievement of the fourth graders' and their motivation towards learning. Damascus University Journal for Educational Sciences, 1, 485-518.

Baldwin-Evans, K. (2006). Key steps to implementing a successful blended learning strategy. Industrial and Commercial Training, 38(3), 156-163.

Blieck, Y., Kauwenberghs, K., Zhu, C., Struyven, K., Pynoo, B., \& DePryck, K. (2019). Investigating the relationship between success factors and student participation in online and blended learning in adult education. Journal of Computer Assisted Learning, 35(4), 476-490.

Bonk, C.J., Kim, K., \& Zeng, T. (2006). Future directions of blended learning in higher education and workplace learning settings. In C.J. Bonk and C.R. Graham (Eds.), Handbook of blended learning: Global perspectives, local designs. San Francisco, CA: Pfeiffer.

Brown, M. G. (2016). Blended instructional practice: A review of the empirical literature on instructors' adoption and use of online tools in face-to-face teaching. The Internet and Higher Education, 31, 1-10.

Cheon, J., Lee, S., Crooks, S. M., \& Song, J. (2012). An investigation of mobile learning readiness in higher education based on the theory of planned behavior. Computers \& Education, 59(3), 1054-1064.

Delialioglu, O., \& Yildirim, Z. (2007). Students' perceptions on effective dimensions of interactive learning in a blended learning environment. Journal of Educational Technology \& Society, 10(2), 133-146.

Drysdale, J. S., Graham, C. R., Spring, K. J., \& Halverson, L. R. (2013). An analysis of research trends in dissertations and theses studying blended learning. The Internet and Higher Education, 17, 90-100.

Ellis, R. A., Steed, A. F., \& Applebee, A. C. (2006). Teacher conceptions of blended learning, blended teaching and associations with approaches to design. Australasian Journal of Educational Technology, 22(3), 312-335.

Euchi, J., Omri, A., \& Al-Tit, A. (2018). The pillars of economic diversification in Saudi Arabia. World Review of Science, Technology and Sustainable Development, 14(4), 330-343. https://doi.org/10.1504/WRSTSD.2018.095719

Fazal, M. and Bryant, M. (2019). Blended Learning in Middle School Math: The Question of Effectiveness. Journal of Online Learning Research, 5(1), 49-64.

Garrison, D. R. and Kanuka, H. (2004). Blended learning: Uncovering its transformative potential in higher education. The Internet and Higher Education, 7(2), 95-105.

George-Walker, L. D., \& Keeffe, M. (2010). Self-determined blended learning: a case study of blended learning design. Higher Education Research \& Development, 29(1), 1-13.

Graham, C. R., Woodfield, W., \& Harrison, J. B. (2013). A framework for institutional adoption and implementation of blended learning in higher education. The Internet and Higher Education, 18, 4-14.

Halverson, L. R., Graham, C. R., Spring, K. J., \& Drysdale, J. S. (2012). An analysis of high impact scholarship and publication trends in blended learning. Distance Education, 33(3), 381-413.

Harris, P., Connolly, J., \& Feeney, L. (2009). Blended learning: Overview and recommendations for successful implementation. Industrial and Commercial Training, 41(3), 155-163.

Hwang, R. H., Lin, H. T., Sun, J. C. Y., \& Wu, J. J. (2019). Improving Learning Achievement in Science Education for Elementary School Students via Blended Learning. International Journal of Online Pedagogy and Course Design (IJOPCD), 9(2), 44-62.

Kiviniemi, M. T. (2014). Effects of a blended learning approach on student outcomes in a graduate-level public health course. $B M C$ Medical Education, 14(1), 47.

Larson, R. C., \& Murray, M. E. (2008). Open educational resources for blended learning in high schools: Overcoming impediments in developing countries. Journal of Asynchronous Learning Networks, 12(1), 85-103.

Lim, D. H., \& Morris, M. L. (2009). Learner and instructional factors influencing learning outcomes within a blended learning environment. Journal of Educational Technology \& Society, 12(4), 282-293.

Makhdoom, N., Khoshhal, K., Algaidi, S., Heissam, K., \& Zolaly, M. (2013). Blended learning' as an effective teaching and learning strategy in clinical medicine: a comparative cross-sectional university-based study. Journal of Taibah University Medical Sciences, 8(1), 12-17.

Means, B., Toyama, Y., Murphy, R., \& Baki, M. (2013). The effectiveness of online and blended learning: A meta-analysis of the empirical literature. Teachers College Record, 115(3), 1-47.

Mitchell, A. and Honore, S. (2007). Criteria for successful blended learning. Industrial and Commercial Training, 39(3), $143-149$. 
Mohammed, G., Hasaballah, A., Almohaimmeed, B., \& Al-Tit, A. (2017). The impact of product performance on brand loyalty mediated by customer satisfaction: Study in Sudanese service industry. International Journal of Advanced and Applied Sciences, 4(1), 116-122. https://doi.org/10.21833/ijaas.2017.01.017

Mozelius, P., \& Hettiarachchi, E. (2017). Critical Factors for Implementing Blended Learning in Higher Education. International Journal of Information and Communication Technologies in Education, 6(1), 4-18.

Owston, R., York, D., \& Murtha, S. (2013). Student perceptions and achievement in a university blended learning strategic initiative. The Internet and Higher Education, 18, 38-46.

Pereira, J. A., Pleguezuelos, E., Merí, A., Molina-Ros, A., Molina-Tomás, M. C., \& Masdeu, C. (2007). Effectiveness of using blended learning strategies for teaching and learning human anatomy. Medical education, 41(2), 189-195.

Poon, J. (2013). Blended learning: an institutional approach for enhancing students' learning experiences. Journal of Online Learning and Teaching, 9(2), 271-288.

Porter, W. W., \& Graham, C. R. (2016). Institutional drivers and barriers to faculty adoption of blended learning in higher education. British Journal of Educational Technology, 47(4), 748-762.

Porter, W. W., Graham, C. R., Bodily, R. G., \& Sandberg, D. S. (2016). A qualitative analysis of institutional drivers and barriers to blended learning adoption in higher education. The internet and Higher education, 28, 17-27.

Porter, W. W., Graham, C. R., Spring, K. A., \& Welch, K. R. (2014). Blended learning in higher education: Institutional adoption and implementation. Computers \& Education, 75, 185-195.

Rahman, M. S., Haque, M. M., \& Hussain, B. (2012). Brand Image and its impact on Consumer's perception: Structural Equation Modelling Approach on Young Consumer's in Bangladesh. Journal of Applied Sciences, 12(8), 768-774.

Riyami, B., Mansouri, K., \& Poirier, F. (2019). Contribution to the multidimensional analysis of the success factors of the integration of the ICTE in higher education in Morocco: Case of the MOOC' relational databases: understanding to master students' point of view. International Journal of Technology Enhanced Learning, 11(1), 80-102.

Rossett, A., Douglis, F., \& Frazee, R. (2003). Strategies for building blended learning. Learning Circuits, 4(7), 1-8.

Rovai, A. P., \& Jordan, H. (2004). Blended learning and sense of community: A comparative analysis with traditional and fully online graduate courses. The International Review of Research in Open and Distributed Learning, 5(2), 1-13.

Schermelleh-Engel, K., Moosbrugger, H., \& Müller, H. (2003). Evaluating the fit of structural equation models: Tests of significance and descriptive goodness-of-fit measures. Methods of Psychological Research Online, 8(2), 23-74.

Shevlin, M., \& Adamson, G. (2005). Alternative factor models and factorial invariance of the GHQ-12: a large sample analysis using confirmatory factor analysis. Psychological Assessment, 17(2), 231-236.

Singh, H. (2003). Building effective blended learning programs. Educational Technology-Saddle Brook Then Englewood Cliffs NJ, 43(6), 51-54.

So, H. J., \& Brush, T. A. (2008). Student perceptions of collaborative learning, social presence and satisfaction in a blended learning environment: Relationships and critical factors. Computers \& Education, 51(1), 318-336.

Stacey, E., \& Gerbic, P. (2008). Success factors for blended learning. In Hello! Where are you in the landscape of educational technology? Proceedings ascilite Melbourne. Avialbale at: http:/ www.ascilite.org.au/conferences/melbourne08/procs/stacey.pdf.

Vaughan, N. (2007). Perspectives on blended learning in higher education. International Journal on E-learning, 6(1), 81-94.

Vodanovich, S. J., Wallace, J. C., \& Kass, S. J. (2005). A confirmatory approach to the factor structure of the Boredom Proneness Scale: Evidence for a two-factor short form. Journal of Personality Assessment, 85(3), 295-303.

Wall, J., \& Ahmed, V. (2008). Lessons learned from a case study in deploying blended learning continuing professional development. Engineering, Construction and Architectural Management, 15(2), 185-202.

Wang, Y., Han, X., \& Yang, J. (2015). Revisiting the blended learning literature: Using a complex adaptive systems framework. Journal of Educational Technology \& Society, 18(2), 380-393.

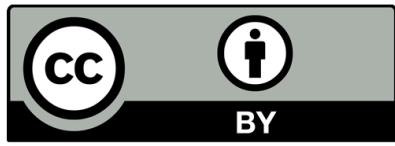

(C) 2021 by the authors; licensee Growing Science, Canada. This is an open access article distributed under the terms and conditions of the Creative Commons Attribution (CC-BY) license (http://creativecommons.org/licenses/by/4.0/). 